\title{
Quality Assessment of Milk in Alexandria
}

\author{
Naglaa F Gomaa*, Mona Hashish*, Mohamed M Kassem*
}

\begin{abstract}
The nutrient value, the chemical, and the microbiological quality of packaged, raw and powder milk samples were assessed. Data were obtained for fat, solid not fat, protein, and calcium contents of milk. Ash percentage, lead, and cadmium concentrations, in addition to possible microbial contamination were also determined. Results showed compliance of long life sterilized packaged milk with Egyptian standards for most of samples, especially in fat and solid not fat contents. These ranged from $3.10-3.80 \%$ and $8.24-9.07 \%$, respectively. Lead content ranged from $0.03-0.55 \mathrm{ppm}$ in liquid milk whereas cadmium ranged from 0.002-0.03 ppm. Protein and calcium contents varied (insignificantly and significantly, respectively) among different milk producing companies. Many $(76.00 \%)$ had total bacterial count in milk higher than Egyptian Standards $(<10 \mathrm{cfu} / \mathrm{ml})$. Buffalo raw milk, and milk powder were complying with Egyptian Standards concerning their nutrient values, however the former had high total bacterial count $\left(4.97 \times 10^{6} \mathrm{cfu} / \mathrm{ml}\right)$ in addition Staphylococcus aureus was detected.
\end{abstract}

\section{INTRODUCTION}

The quality control assessment is a changes in the product itself.(3-7) Among matter of prime interest for food producers. these defects, light-induced off-flavours are The society is becoming more and more probably the most common in milk sensitive about the quality of the food attributed to two distinct causes. The first, a which is consumed.(1) Milk quality "burnt sunlight flavour" develops during the deterioration is perceived by the consumer through off-flavours that may be caused by both feeding conditions of the animal with first 2 or 3 days of storage and is caused by degradation products of sulfur containing amino acids of the whey certain pastures $^{(2)}$ or chemical, proteins $^{(8)}$ mainly methional(9) The second physicochemical, or microbiological is a metallic or cardboardy off-flavour that

\footnotetext{
* Food Hygiene and Control, High Institute of Public Health, Alexandria, Egypt.

* microbilegy, High Institute of Public Health ,Alexandria, Egypt.

** Food Hygiene and Control, Nutrition Institute, Cairo, Egypt
} 
develops 2 days later and does not dissipate. This off-flavour is attributed to lipid oxidation. ${ }^{(10)}$ These degradation will result in changes in the normal protein and fat contents of milk. According to the Egyptian Organization for Standardization and Quality, cows raw milk and long life sterilized cows packed milk should contain not less than $3 \%$ fat and not less than 8.25\% solid not fat. ${ }^{(11,12)}$ Raw Buffalos milk, on the other hand, should contain not less than $5.5 \%$ fat and not less than $8.75 \%$ solid not fat.(11) For whole milk powder, fat content should range between $26 \%$ to less than $42 \%$.(13) Lactating cows may possibly be exposed to high quantities of toxic metals, such as $\mathrm{Cd}$ and $\mathrm{Pb}$, in the environment. $^{(14)}$ The relationship between environmental lead pollution and lead in milk showed concentrations of 1600 to $1900 \mu \mathrm{g} / \mathrm{kg}$ of milk produced by cows in a contaminated area compared to $20 \mu \mathrm{g} / \mathrm{kg}$ in an uncontaminated area. In the contaminated area the lead concentration in the hay was from 10 to 43 times that in the uncontaminated area. However, not all of the increase of lead in milk can be attributed to consumption of contaminated feeds since it was reported that only $0.003 \%$ of the ingested lead transfers to the milk. Lead concentrations in 40 raw milk samples from regions of varying air pollution in Germany had concentrations from 14 to $67 \mu \mathrm{g} / \mathrm{kg}$ ( $^{(15)}$ The main factors affecting the keeping quality of long life sterilized or pasteurized milk are raw milk quality, severity of heat treatment, post processing contamination, and storage temperature. (16) Packaging is also a factor of utmost importance effectively protecting the product from microbial recontamination. ${ }^{(17)}$ In order to realize a successful total quality management program in packaged milk producing plants, antibiotic-free milk should be only used.(18)The objective of this study was to evaluate the nutritive value, the chemical contamination with $\mathrm{Pb}$ and $\mathrm{Cd}$ and the 
microbiological stability of long life sterilized packaged milk, fresh milk and powder milk and to test compliance with Egyptian standards.

\section{MATERIAL AND METHODS}

\section{Sampling}

A total of 60 milk samples were collected from the local market of Alexandria Governorate. These comprised 44 packaged milk samples (4 samples from each of 11 packaged milk producing companies. These were almost all companies in Alexandria market 2007), 8 samples of powder milk (4 samples from each of 2 milk powder producing companies), in addition to 8 unpackaged raw milk collected from the market.

\section{Chemical tests}

\section{Fat determination}

Fat content of milk samples was determined using Gerber method for fat determination and expressed as percentage of milk fat. ${ }^{(19)}$

\section{Solid not fat determination}

Solid not fat content of milk was determined using the method described in the Egyptian standards 155/1974. ${ }^{(19)}$

\section{Protein determination}

Milk protein content was determined on $10 \mathrm{~g}$ milk by the macro Kjeldahl method using the factor $\mathrm{N} \times 6.38 .^{(20)}$

\section{pH determination}

$\mathrm{pH}$ of liquid milk and acidity of powder milk were determined according to the method described in the Egyptian standards 155/1974. ${ }^{(19)}$

\section{Ash determination}

Ash content of milk samples was determined by heating the dried residue of milk at a temperature not exceeding $500^{\circ} \mathrm{C}$ so that the chlorides are not volatilized. ${ }^{(20)}$

\section{Calcium determination}

Calcium content of milk was determined according to the method described in Pearson's chemical analysis of foods ${ }^{(20)}$ using Atomic Absorption 
spectroscopy (SCHIMADSU AA-680 flame system).

\section{Lead and cadmium determination}

The ashing method suggested by king and Dunkley was used.(21) Then $\mathrm{Pb}$ and $\mathrm{Cd}$ concentrations were determined after injection in Atomic Absorption spectroscopy (SCHIMADSU AA-680 flame system).(20)

\section{Antibiotics residues detection}

A rapid test for $\beta$-lactam and Tetracycline residues was done using Twin sensor BT kit (product reference: BT00640).(22)

\section{Microbiological examination}

All milk samples were subjected to the following tests.

1- Standard heterotrophic plate count using pour plate method.

2- Detection of $E$. coli using multiple tube dilution method.

3- Detection of Staphylococcus aureus.
4- Detection of Salmonella.

5- Detection of Clostridium perfringens.

6- Enumeration of mold and yeast. All the microbiological procedures were performed according to the methods described in Bacteriological Analytical manual (2001).(23)

\section{RESULTS}

Table (1) illustrates the comparison between the nutrient contents of milk samples. All of long life sterilized packaged milk, Buffalo milk and powder milk had fat content that complied with Egyptian Standards (not less than 3\%). Only 2 companies (3 and 7) had solid not fat complying with Egyptian Standards (should be not less than $8.25 \%$ ). All samples varied insignificantly $(P=0.168)$ and significantly $(P=0.001)$ regarding their contents of protein and calcium, respectively. Buffalo milk was higher significantly in all nutrient contents. 
Table (1): $\quad$ Comparison between the nutrient contents of milk samples.

\begin{tabular}{|c|c|c|c|c|c|}
\hline \multirow{2}{*}{\multicolumn{2}{|c|}{$\begin{array}{l}\text { Company } \\
\text { code }\end{array}$}} & \multicolumn{4}{|c|}{ Nutrient contents } \\
\hline & & \multirow{2}{*}{$\frac{\mathrm{Fat}^{\dagger+}(\%)}{3.40 \pm 0.00}$} & \multirow{2}{*}{$\begin{array}{c}\text { Solid not fat (\%) } \\
9.07 \pm 0.00\end{array}$} & \multirow{2}{*}{$\begin{array}{c}\text { Protein (\%) } \\
3.83 \pm 0.08 \\
\end{array}$} & \multirow{2}{*}{$\begin{array}{c}\text { Calcium (ppm) } \\
927.17 \pm 37.84\end{array}$} \\
\hline$\stackrel{x}{=}$ & 1 & & & & \\
\hline 8 & 2 & $0.60 \pm 0.00^{\dagger}$ & $9.01 \pm 0.00$ & $4.19 \pm 0.27$ & $926.62 \pm 39.12$ \\
\hline$\Phi$ & 3 & $3.35 \pm 0.06$ & $8.24 \pm 0.20^{\dagger+\dagger}$ & $2.99 \pm 0.97$ & $850.29 \pm 82.97$ \\
\hline 焉 & 4 & $3.50 \pm 0.00$ & $8.75 \pm 0.00$ & $3.70 \pm 0.23$ & $945.04 \pm 28.76$ \\
\hline$\stackrel{\varpi}{2}$ & 5 & $3.50 \pm 0.00$ & $8.74 \pm 0.00$ & $3.86 \pm 0.15$ & $827.15 \pm 50.02$ \\
\hline$\overline{8}$ & 6 & $3.10 \pm 0.00$ & $8.64 \pm 0.03$ & $3.90 \pm 0.32$ & $853.68 \pm 19.05$ \\
\hline$\stackrel{\bar{n}}{=}$ & 7 & $3.80 \pm 0.00$ & $8.23 \pm 0.00^{t+t}$ & $3.93 \pm 0.01$ & $1161.32 \pm 116.49$ \\
\hline$\frac{1}{0}$ & 8 & $3.05 \pm 0.06$ & $8.49 \pm 0.12$ & $3.61 \pm 0.01$ & $873.96 \pm 90.12$ \\
\hline$\stackrel{\infty}{ \pm}$ & 9 & $3.40 \pm 0.00$ & $8.70 \pm 0.00$ & $3.53 \pm 0.22$ & $844.78 \pm 8.34$ \\
\hline ס) & 10 & $3.10 \pm 0.00$ & $8.57 \pm 0.07$ & $4.56 \pm 1.51$ & $1034.53 \pm 38.72$ \\
\hline בَّ & 11 & $3.10 \pm 0.00$ & $8.50 \pm 0.02$ & $4.07 \pm 0.11$ & $873.91 \pm 65.82$ \\
\hline \multicolumn{2}{|c|}{ Average $(n=44)$} & $3.33 \pm 0.24$ & $8.36 \pm 0.27$ & $3.84 \pm 0.41$ & $919.86 \pm 99.93$ \\
\hline \multicolumn{2}{|c|}{ Test of significance } & $\begin{array}{c}38.216^{\star a} \\
(P<0.001)\end{array}$ & $\begin{array}{l}50.199^{* b} \\
(P<0.001)\end{array}$ & $\begin{array}{c}1.658^{\mathrm{b}} \\
(\mathrm{P}=0.168)\end{array}$ & $\begin{array}{c}7.853^{*} \mathrm{~b} \\
(\mathrm{P}<0.001)\end{array}$ \\
\hline \multicolumn{2}{|c|}{ Buffalo milk $(n=8)$} & $6.70 \pm 0.00$ & $9.80 \pm 0.00$ & $5.08 \pm 0.31$ & $1277.72 \pm 127.19$ \\
\hline \multicolumn{2}{|c|}{ Test of significance } & $\begin{array}{c}3.353^{*} \mathrm{C} \\
(\mathrm{P}<0.001)\end{array}$ & $\begin{array}{c}3.606^{* d} \\
(P<0.001)\end{array}$ & $\begin{array}{c}3.89^{* d} \\
(P=0.001)\end{array}$ & $\begin{array}{c}7.087^{*} \mathrm{~d} \\
(\mathrm{P}<0.001)\end{array}$ \\
\hline \multicolumn{2}{|c|}{ Powder milk $(n=8)$} & $29.75 \pm 0.27$ & - & $32.01 \pm 0.99$ & $6889.48 \pm 2259.18$ \\
\hline
\end{tabular}

$\mathrm{n}=$ number of samples

*statistically significant at $\mathrm{P}<0.05$.

${ }^{a} x^{2}$ for Kruskal-Wallis test.

${ }^{b} \mathrm{~F}$ test (ANOVA).

cZ for Mannwhitney test.

d Student t-test.

† Skim milk, fat not included in average.

t† Complied with Egyptian standards (fat not less than 3\%).

ttt Not complying with Egyptian standards (solid not fat not less than $8.25 \%$ ).- $11.53 \%$ of liquid milk had solid not fat less than $8.25 \%$. 
Table (2) shows $\mathrm{pH}$, Ash, heavy metals, and antibiotic residues of milk samples. The $\mathrm{pH}$ of milk samples varied significantly $(p=0.001)$, it was lower in milk of companies 8 and $9 \quad(6.55 \pm 0.10$ and 6.55 \pm 0.13 , respectively) and was higher in company 6 (6.80 \pm 0.00$)$. Ash content was not complying with Egyptian Standards as it was less than $0.7 \%$ in most of the long life sterilized packaged milk except in company $2(0.71 \pm 0.02 \%)$ and company 5 $(0.71 \pm 0.01 \%)$. The mean ash $\%$ in Buffalo milk was found to be higher significantly than the long life sterilized packaged milk $(P=0.024)$. Lead and Cadmium content of milk samples varied (significantly and insignificantly, respectively). They ranged from a minimum of $\quad 0.03 \pm 0.02 \%$ to $0.55 \pm 0.18 \%$ for Lead and ranged from $0.002 \pm 0.002 \%$ to $0.03 \pm 0.01 \%$ for Cadmium. Antibiotic residues were detected in 3 milk samples of the long life sterilized packaged milk (companies 6,8, and 11).
Table (3) demonstrates the microbiological content of milk samples.

The total bacterial count of long life sterilized packaged milk varied significantly $(P=0.006)$. It ranged from $<10 \mathrm{cfu} / \mathrm{ml}$ (companies 2, 9, and 10) to a high of 6.22 $\times 10^{3} \pm 1.23 \times 1.23 \times 10^{4} \mathrm{cfu} / \mathrm{ml}$ (company 4). On the other hand, mold and yeast count was $<10 \mathrm{cfu} / \mathrm{ml}$ and no pathogens including; Staph aureus, Salmonella spp. and Clostridium perfringens were detected in all milk samples.

For Buffalo milk, the mean total bacterial count was as high as $4.97 \times 10^{6}$ $\pm 2.16 \times 10^{6} \mathrm{cfu} / \mathrm{ml}$. Mold and yeast count was $1.07 \times 10^{3} \pm 2.62 \times 10^{2} \mathrm{cfu} / \mathrm{ml}$. Fecal coliform count was $>1100 \mathrm{MPN} / \mathrm{ml}$. in addition, Staph aureus was detected at a mean count of $1.28 \times 10^{3} \pm 1.80 \times 10^{3}$ $\mathrm{cfu} / \mathrm{ml}$.

Moreover, powder milk had bacterial and mold and yeast counts of $<10 \mathrm{cfu} / \mathrm{g}$ and no pathogens were detected. 
Table (2):Comparison between the $\mathrm{pH}$, ash, heavy metals( Lead and Cadmium) and antibiotic residues of milk samples.

\begin{tabular}{|c|c|c|c|c|c|c|}
\hline \multirow{2}{*}{\multicolumn{2}{|c|}{$\begin{array}{l}\text { Company } \\
\text { code }\end{array}$}} & \multicolumn{5}{|c|}{ Chemical content } \\
\hline & & \multirow{2}{*}{$\frac{\mathbf{p H}}{6.60 \pm 0.00}$} & \multirow{2}{*}{$\begin{array}{c}\text { Ash (\%) } \\
0.67 \pm 0.02\end{array}$} & \multirow{2}{*}{$\begin{array}{c}\begin{array}{c}\text { Lead } \\
\text { (ppm) }\end{array} \\
0.03 \pm 0.02\end{array}$} & \multirow{2}{*}{$\begin{array}{c}\begin{array}{c}\text { Cadmium } \\
\text { (ppm) }\end{array} \\
0.002 \pm 0.02\end{array}$} & \multirow{2}{*}{$\begin{array}{c}\begin{array}{c}\text { Antibiotic } \\
\text { residues }\end{array} \\
\text { N.D }\end{array}$} \\
\hline \multirow{11}{*}{ 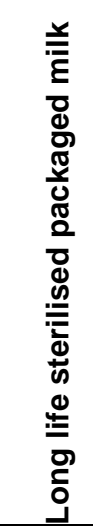 } & 1 & & & & & \\
\hline & 2 & $6.64 \pm 0.01$ & $0.71 \pm 0.02^{\dagger^{*}}$ & $0.55 \pm 0.18^{1 \dagger^{*}}$ & $0.014 \pm 0.11$ & N.D \\
\hline & 3 & $6.64 \pm 0.03$ & $0.66 \pm 0.02$ & $0.38 \pm 0.40^{\dagger t^{*}}$ & $0.02 \pm 0.02$ & N.D \\
\hline & 4 & $6.67 \pm 0.00$ & $0.69 \pm 0.05$ & $0.05 \pm 0.04$ & $0.01 \pm 0.01$ & N.D \\
\hline & 5 & $6.68 \pm 0.00$ & $0.71 \pm 0.01^{\dagger^{*}}$ & $0.07 \pm 0.01$ & $0.02 \pm 0.01$ & N.D \\
\hline & 6 & $6.80 \pm 0.00$ & $0.69 \pm 0.03$ & $0.18 \pm 0.11$ & $0.02 \pm 0.01$ & $\begin{array}{l}\text { +ve ßeta-lactam, } \\
\text { +ve Tetracycline }\end{array}$ \\
\hline & 7 & $6.60 \pm 0.000$ & $0.64 \pm 0.01$ & $0.11 \pm 0.00$ & $0.03 \pm 0.01$ & -ve \\
\hline & 8 & $6.55 \pm 0.10$ & $0.51 \pm 0.00$ & $0.31 \pm 0.02^{\dagger \dagger^{*}}$ & $0.01 \pm 0.00$ & +ve Tetracycline \\
\hline & 9 & $6.55 \pm 0.13$ & $0.53 \pm 0.01$ & $0.16 \pm 0.08$ & $0.02 \pm 0.01$ & -ve \\
\hline & 10 & $6.64 \pm 0.01$ & $0.66 \pm 0.01$ & $0.18 \pm 0.15$ & $0.02 \pm 0.01$ & -ve \\
\hline & 11 & $6.60 \pm 0.00$ & $0.5 \pm 0.01$ & $0.26 \pm 0.00^{t t^{*}}$ & $0.01 \pm 0.00$ & +ve Tetracycline \\
\hline \multicolumn{2}{|c|}{$\begin{array}{c}\text { Average } \\
(n=44)\end{array}$} & $6.63 \pm 0.07$ & $0.64 \pm 0.07$ & $0.21 \pm 0.16^{\dagger t^{*}}$ & $0.02 \pm 0.01$ & - \\
\hline \multicolumn{2}{|c|}{$\begin{array}{c}\text { Test of } \\
\text { significance }\end{array}$} & $\begin{array}{c}30.582^{*} \mathrm{~d} \\
(P=0.001)\end{array}$ & $\begin{array}{c}22.396^{* b} \\
(P=0.001)\end{array}$ & $\begin{array}{c}2.557^{*} \mathrm{~b} \\
(\mathrm{P}=0.046)\end{array}$ & $\begin{array}{c}0.743^{b} \\
(P=0.678)\end{array}$ & - \\
\hline \multicolumn{2}{|c|}{$\begin{array}{l}\text { Buffalo milk } \\
(n=8)\end{array}$} & $6.67 \pm 0.00$ & $0.735 \pm 0.011$ & $0.27 \pm 0.07^{\dagger \dagger^{*}}$ & $0.03 \pm 0.00$ & -ve \\
\hline \multicolumn{2}{|c|}{$\begin{array}{c}\text { Test of } \\
\text { significances }\end{array}$} & $\begin{array}{c}1.394^{c} \\
(P=0.184)\end{array}$ & $\begin{array}{c}2.366^{* d} \\
(P=0.024) \\
\end{array}$ & $\begin{array}{c}0.351^{\mathrm{d}} \\
(\mathrm{P}=0.728) \\
\end{array}$ & $\begin{array}{c}1.488^{\mathrm{d}} \\
(\mathrm{P}=0.146)\end{array}$ & - \\
\hline \multicolumn{2}{|c|}{$\begin{array}{l}\text { Powder milk } \\
\quad(n=8)\end{array}$} & $0.90^{\dagger} \pm 0.03$ & $5.64 \pm 0.04$ & $1.30 \pm 0.77^{\dagger \dagger^{*}}$ & $0.15 \pm 0.01$ & -ve \\
\hline
\end{tabular}

$\mathrm{n}=$ number of sample. N.D. $=$ Not detected

* statistically significant at $\mathrm{P}<0.05$.

${ }^{a} x^{2}$ For kruskal Wallis test.

${ }^{b} \mathrm{~F}$ test (ANOVA).

${ }^{\mathrm{c}} \mathrm{z}$ for mannwhitney test.

${ }^{\mathrm{d}}$ student t-test.

${ }^{\dagger}$ Acidity of powder milk.

$\dagger^{\star}$ Complying with Egyptian standards (Ash\% not less then $\left.0.7 \%\right)-(34.21 \%$ of liquid milk)

$\mathrm{t \dagger}^{\star}$ Not complying with Egypt standards (lead $<0.2 \mathrm{mg} / \mathrm{kg}$ and Cadmium should not be detected) $54.30 \%$ of all milk samples had lead $>0.2 \mathrm{ppm}$ while nearly all samples conained Cadmium (95.23\%). 
Table (3): Microbiological content of milk samples

\begin{tabular}{|c|c|c|c|c|c|c|c|}
\hline \multicolumn{2}{|c|}{$\begin{array}{c}\text { Company } \\
\text { code }\end{array}$} & \multicolumn{6}{|c|}{ Microbiological content } \\
\hline \multirow{12}{*}{ 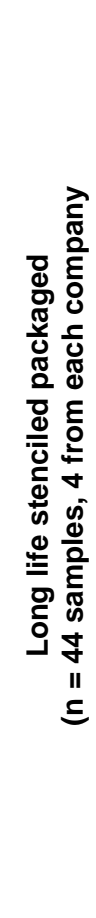 } & & $\begin{array}{c}\text { Total bacerial } \\
\text { count }{ }^{\dagger} \\
\text { (cfu/ml) }\end{array}$ & $\begin{array}{l}\text { Yeast and } \\
\text { Mold } \\
(\mathrm{CPU} / \mathrm{ml})\end{array}$ & $\begin{array}{c}\text { Focal } \\
\text { celiform } \\
(\mathrm{MPN} / \mathrm{ml})\end{array}$ & $\begin{array}{c}\text { Staphylococcus } \\
\text { aureus }\end{array}$ & $\begin{array}{l}\text { Salmonell } \\
\text { a spp. }\end{array}$ & $\begin{array}{l}\text { Clostridium } \\
\text { perfringens }\end{array}$ \\
\hline & 1 & $\begin{array}{c}3.28 \times 10^{2} \\
\pm 1.61 \times 10^{2} \\
\end{array}$ & $<10$ & -ve & -ve & -ve & -ve \\
\hline & 2 & $<10$ & $<10$ & -ve & -ve & -ve & -ve \\
\hline & 3 & $\begin{array}{c}5.33 \times 10 \\
\pm 4.50 \times 10\end{array}$ & $<10$ & -ve & - ve & -ve & -ve \\
\hline & 4 & $\begin{array}{c}6.22 \times 10^{3} \\
\pm 1.23 \times 10^{4}\end{array}$ & $<10$ & -ve & - ve & -ve & -ve \\
\hline & 5 & $\begin{array}{c}7.75 \times 10^{2} \\
\pm 1.15 \times 10^{3} \\
\end{array}$ & $<10$ & -ve & - ve & -ve & -ve \\
\hline & $6^{\dagger}$ & $\begin{array}{c}6.90 \times 10^{2} \\
\pm 7.77 \times 10^{2} \\
\end{array}$ & $<10$ & -ve & - ve & -ve & -ve \\
\hline & 7 & $\begin{array}{c}1.50 \times 10^{2} \pm \\
0.00\end{array}$ & $<10$ & -ve & - ve & -ve & -ve \\
\hline & 8 & $\begin{array}{c}3.00 \times 10^{2} \pm \\
0.00\end{array}$ & $<10$ & -ve & - ve & -ve & -ve \\
\hline & 9 & $<10$ & $<10$ & -ve & - ve & -ve & -ve \\
\hline & 10 & $<10$ & $<10$ & -ve & - ve & -ve & -ve \\
\hline & 11 & $\begin{array}{c}1.50 \times 10^{2} \pm \\
0.00\end{array}$ & $<10$ & -ve & - ve & -ve & -ve \\
\hline \multicolumn{2}{|c|}{$\begin{array}{l}\text { Average } \\
(n=44)\end{array}$} & $\begin{array}{c}7.9 \times 10^{2} \\
\pm 1.8 \times 10^{3} \\
\end{array}$ & $<10$ & -ve & - ve & -ve & -ve \\
\hline \multicolumn{2}{|c|}{$\begin{array}{c}\text { Test of } \\
\text { significanc } \\
\mathrm{e} \\
\end{array}$} & $\begin{array}{c}23.256^{\star a} \\
(P=0.006)\end{array}$ & - & - & - & - & - \\
\hline \multicolumn{2}{|c|}{$\begin{array}{c}\text { Buffalo } \\
\text { milk }(n=8)\end{array}$} & $\begin{array}{c}4.97 \times 10^{6} \\
\pm 2.16 \times 10^{6} \\
\end{array}$ & $\begin{array}{c}1.07 \times 10^{3} \\
\pm 2.62 \times \\
10^{2}\end{array}$ & $>1100$ & $\begin{array}{c}1.28 \times 10^{3} \\
\pm 1.80 \times 10^{3}\end{array}$ & -ve & -ve \\
\hline \multicolumn{2}{|c|}{$\begin{array}{c}\text { Test of } \\
\text { significance } \\
\mathrm{s} \\
\end{array}$} & $\begin{array}{c}0.00 \\
(P=0.190)^{*} d\end{array}$ & - & - & - & - & - \\
\hline \multicolumn{2}{|c|}{$\begin{array}{c}\text { Powder } \\
\text { milk }(n=8)\end{array}$} & $<10$ & $<10$ & -ve & -ve & -ve & -ve \\
\hline
\end{tabular}

$\mathrm{n}=$ number of samples

* statistically significant at $\mathrm{P}<0.05$.

†pasteurized milk, not included in statistical analysis.

t† $76.00 \%$ of samples of long life sterilized milk were not complying with Egyptian Standards $(<10$ $\mathrm{cfu} / \mathrm{ml}) . \quad{ }^{\mathrm{a}} \mathrm{X}^{2}$ for Kurskal Wallis test $\quad{ }^{\mathrm{d}}$ student $\mathrm{t}$-Test. 


\section{DISCUSSION}

The quality of food, such as milk and dairy products may be defined as that sum of characteristics which enable the food to satisfy definite requirements and which determine its fitness for consumption. (24) In this sense, quality can be judged by means of sensory evaluation, its nutritive value, and according to its chemical, physical, and microbiological characteristics. The Egyptian Standards for Specification have set standards controlling the production of long-life sterilized (packaged) milk, of raw milk and of powder milk, in order to ensure good quality and safe milk reaching consumers. ${ }^{(11-13)}$ All long life sterilized packaged milk samples consisted of cows milk. These had fat percentages that ranged from a minimum of $3.10 \pm 0.00 \%$ to a maximum of $3.80 \pm 0.00 \%$. Solid not fat percentages, on the other hand, ranged from $8.23 \pm 0.00 \%$ (company 7 ) to $9.07 \pm$ 0.00 (company 1). Hence, all samples had fat percentages complying with Egyptian standards for cows milk (should not be less than 3\%).(11) They were also complying with Egyptian Standards concerning solid not fat percentages (not less than $8.25 \%)^{(11)}$ except for company 3 (8.24 \pm $0.20 \%)$ and company $7(8.23 \pm 0.00 \%)$ as shown in table 1. Regarding protein percentages, it was minimum in company $3(2.99 \pm 0.97 \%)$ and was maximum in company 10 (4.65 $\pm 1.51 \%)$. Similarly calcium content ranged from $827.15 \pm$ $50.02 \%$ ppm (company 5) to $1161.32 \pm$ 116.49 ppm (company 7) as seen in table 1. This variation in nutrient content of longlife sterilized milk among the different companies might be attributed to the fact that these companies receive milk from different big or small farms producing milk with varying nutrient composition and hence, tended to add reconstituted milk powder (as sometimes indicated on the package) in order to cope with the nutrient's limits set by Egyptian standards. The main problem in milk production in 
these farms especially in the small producers group which are the most numerous, is the unsuitable systems for feeding cows. This problem is due to inadequate general management of the farm business and limited economic resources of the farmers. Nevertheless, the general low educational level of farmers and particularly the cow feeding and economic farm management have contributed to the problem as well. ${ }^{(25)}$ Table 1 also shows that powder milk had high fat $(29.75 \pm 0.27 \%)$, protein $(32.01 \pm 0.99 \%)$, and calcium (6889.48 \pm 2259.18 ppm) contents. This is the result of the concentration of the milk during the drying process which increases the percentages of fat, protein and calcium.(26) These agreed with the Egyptian Standards for milk powder where fat percentage should range between $26 \%$ and $<42 \%$.(13) Whereas, protein content agreed with the result of another study where the protein percentage of commercial non-fat dry milk was
$35.24 \%$.(26) Although powder milk was added to raise the nutrient content of long life packaged sterilized milk as mentioned above, the nutrient content of Buffalo milk samples was the best. The mean fat content was $6.70 \pm 0.00 \%$, the mean solid not fat content was $9.80 \pm 0.00 \%$, the mean protein content was $5.08 \pm 0.31 \%$ and the calcium content was $1277.72 \pm 127.19 \mathrm{ppm}$. All of these were significantly higher than nutrient content of the long life packaged sterilized cows milk $(P<0.001)$. Results in table 2 indicated that the $\mathrm{pH}$ of all liquid milk samples ranged from $6.55 \pm 0.103$ (company 8) to $6.80 \pm 0.0$ (company 6) while the mean acidity of powder milk was $0.9 \pm 0.03$.These complied with Egyptian standards. ${ }^{(11-13)}$ Concerning ash content, it was as low as $0.51 \pm 0.00 \%$ (company 8 ) and was as high as $0.74 \% \pm 0.01$ in Buffalo milk. According to the Egyptian standards, ash \% should not be less than $0.7 \%$ in liquid milk.(18) Generally, a considerably higher ash percentage than $0.7 \%$ will 
indicate the addition of foreign matter to milk, whereas, a lower ash percentage than $0.7 \%$ might indicate the addition of water. ${ }^{(19)}$ Small amounts of Lead occur in many foods naturally but contamination may also occur from the use of lead alloys or compounds for processing materials, including solders, glazes, enamels and wrapping materials. On the other hand, cadmium in food arises mainly from natural sources, but it may also be derived from atmospheric discharge into water and the enhanced uptake by plants due to the use of super phosphate fertilisers or the disposal of sewage sludge on land.(20) In this study Lead content in liquid milk ranged from $0.03 \pm 0.02 \mathrm{ppm}$ (company 1 ) to $0.55 \pm 0.18 \mathrm{ppm}$ (company 2). Lead was higher in milk powder (1.30 $\pm 0.77 \mathrm{ppm})$. For cadmium, it was $0.002 \pm 0.002 \mathrm{ppm}$ (company 1) to $0.026 \pm 0.008 \mathrm{ppm}$ (company 7) for liquid milk and had a high average mean content of $0.15 \pm 0.01 \mathrm{ppm}$ for powder milk. It should be mentioned that powder milk is imported from other countries but packaged in Egypt. Lead (at concentrations higher than $0.2 \mathrm{ppm}$ ) and cadmium were detected in $54.30 \%$ and $95.23 \%$ of milk samples. According to the Egyptian Standards, Lead content in milk should be less than 0.2 ppm while Cadmium should not be detected.(27)In another study, the mean concentration of lead in raw milk samples varied between 0.091 to $0.1 \mathrm{ppm}$, whereas, the mean concentration of cadmium varied between 0.006 and 0.010 ppm. ${ }^{(19)}$ Much lower concentrations were recorded in a more recent study, where the mean $\mathrm{Cd}$ and $\mathrm{Pb}$ contents were found to be $0.044 \times 10^{-3} \mathrm{ppm}$ and $2.03 \times 10^{-3} \mathrm{ppm}$, respectively. ${ }^{(14)}$ In the US, current lead levels in foods are in the range of $0.1-0.3 \mathrm{ppm}$ (in beverages they are $0.02-0.03 \mathrm{ppm})^{(28)}$. The rapid twin sensor BT test revealed the contamination of some of the examined milk samples with antibiotic residues (Beta-lactam and/or tetracycline) as seen in table 2. Milk from 
individual cows clearly should be tested to ensure that antibiotic-free milk is leaving the farm. The milk testing program should become a component of the quality process that is centered on the farm and that measures the success of the industry in producing high quality milk rather than being a regulatory program that searches for a flawed product. ${ }^{(18)}$ Milk is a very rich culture media for a wide variety of microorganisms. In fact, bacteria contamination is the main cause of milk spoilage, being the sterility control the main task in the post-process quality assessment of milk production. ${ }^{(29)}$ Results in table 3 shows that all samples of long life sterilized packaged milk and milk powder were free from E. coli, Staphylococcus aureus, Salmonella spp, and Clostridium perfringens. These results complied with Egyptian standards. ${ }^{(12,13)}$

Concerning raw milk, Staphylococcus aureus was the only pathogen detected but at counts of $1.28 \times 10^{3} \pm 1.80 \times 10^{3} \mathrm{cfu} / \mathrm{ml}$ which was higher than those of the Egyptian standards $\quad\left(10^{2} \mathrm{cfu} / \mathrm{ml}\right) \cdot{ }^{(11)}$ Regarding mold and yeast count, it was $<10 \mathrm{cfu} / \mathrm{ml}$ for most of milk samples. However, total bacterial counts varied among the collected milk samples; counts ranged from $<10$ (company 9,10 and milk powder) to $6.22 \times 10^{3} \pm 1.23 \times 10^{4}$ (company 4). Hence, many company producing long life sterilized packaged milk were not complying with the Egyptian standards regarding total bacterial count which should not exceed $10 \mathrm{cfu} / \mathrm{ml}^{(12)}$ This is an indication of the poor milk collection practices. ${ }^{(17)}$

\section{CONCLUSION}

All packaged long life sterilized milk samples complied with Egyptian standards concerning fat content, whereas $11.53 \%$ were not complying in solid not fat content. Protein and calcium contents varied insignificantly and significantly, respectively, among milk samples which necessitate farmer's education about cow feeding and 
economic farm management. Ash content was sometimes lower than the $0.7 \%$ set by the Egyptian Standards in long life sterilized milk. This might indicate adulteration with water. For $\mathrm{Pb}$ and $\mathrm{Cd}$, they were detected at levels as high as $0.55 \mathrm{ppm}$ and $0.03 \mathrm{ppm}$, respectively in liquid milk and as high as $1.30 \mathrm{ppm}$ and $0.15 \mathrm{ppm}$, respectively, in the imported powder milk, the latter might be a contributing factor for $\mathrm{Pb}$ and $\mathrm{Cd}$ content of the long life sterilized milk. More control is needed at this point to be able to cope with food regulations which tend to decrease heavy metals contaminants in foods. The microbiological content of milk need much more attention. Companies should not receive milk with high microbial load, as this will affect the microbial content in the final packaged milk.

\section{RECOMMENDATIONS}

Although Buffalo milk had higher significantly microbial content, considerable decrease will occur through effective heat treatment. Hence we recommend to increase consumption of Buffalo milk due to its higher nutritive value especially that packaged sterilized milk was found to contain; microbial content, lower ash content indicating possible addition of water , Lead (>0.2ppm)and Cadmium contents that did not differ significantly from Buffalo milk and most of all it contained antibiotic residues.

\section{ACKNOWLEDGEMENTS}

The authors thank Mr. Ahmed El-Dawi Abd El-Aal and Mrs. Soad Gabara for their valuable assistance.

\section{References}

1. Elvira L, Sampedra L, mtesanz J, Gomez-Ullate Y, Resa P, Iglesias JR, et al. Non-invasive and destructive ultrasonic technique for the detection of microbial contamination in packed UHT milk. Food research International. 2005; 38: 631-8.

2. Palmquist, DL, Beaulieu AD, Barbano DM. Feed and animal factors influencing milk fat composition. Journal of Dairy Sience. 1993;76: 1753-71.

3. Thomas EL.Trends in milk flavors. Journal of Dairy Science. 1981; 64: 1023-7.

4. Allen JC, Joseph G. Deterioration of pasteurized milk on storage. Journal of Dairy Research. 1985; 52: 469-87. 
5. Rysstad G, Ebbesey A, Eggestad, J.Sensory and chemical quality of UHT milk stored in paperboard cartons with different oxygen and light barriers. Food Additives and Contaminants. 1998;15(1): 112-22.

6. Valero E, Villamiel M., Sanz J, MartinezCastro I. Chemical and sensorial changes in milk quality on the keeping quality of pasteurized milk. Letters in Applied Microbiology. 2000; 20: 164-7.

7. Van Aardt M, Duncan SE, Marcy JE, Long TE, Hackey CR. Effectiveness of poly(ethylene terephthalate) and.high-density polyethelene in protection of milk flavor. Journal of Dairy Science. 2001; 84:1341-7.

8. Marsili RT. Comparison of SPME and dynamic headspace method for the GC-MS analysis of light-induced lipid oxidation products in milk. Journal of Chromatography Science. 1999; 37: 17-23.

9. Borle, F, Sieber R, Bosset LO. Photooxidation and photoprotection of foods, with particular reference to dairy products - An update of a review article (1993-2000). Sciences des Aliments.2001; 21(6): 571-90.

10. Barnard SE. Importance of shelf life for consumers of milk. Journal of Dairy Science.1972; 55: 134-136.

11. Egyptian standards. Milk and milk products Part1: Raw milk (1-154) Arab Republic of Egypt: Egyptian Organization for Standardization and Quality Control; 2005.

12. Egyptian standards. Long life sterilized milk (1623) Arab Republic of Egypt: Egyptian Organization for Standardization and Quality Control; 2005.

13. Egyptian standards. Milk powder (1648) Arab Republic of Egypt: Egyptian Organization for Standardization and Quality Control; 2005.
14. Jeng SL, Lee SJ, Lin SY. Determination of cadmium and lead in raw milk by Graphite Furnace Atomic Absorption Spectrophotometer. J Dairy Sci. 1994; 77: 945-9.

15. Bruhn JC, Franke AA. Lead and cadmium in coliformia raw milk. 1976; 26: 1711-1717.

16. IDF (International Dairy Federation). Bulletin 200. pasteurization. 1986.

17. Zygoura P, Moyssiadi T, Badeka A, Kandyli E, Savvaidis I, Kontominas MG. Shelf life of whole pasteurized milk in Greece: effect of packaging material. Food Chemistry. 2004; 84: 19.

18. Sischo WM. Symposium: Drug residue avoidance: The issue of testing quality milk and tests for antibiotic residues. J Dairy Sci. 1996; 79: 1065-73.

19. Egyptian Standards. Physical and chemical standards for analysis of milk and dairy products (155) Arab Republic of Egypt: Egyptian Organization for Standardization and Quality Control;1974.

20. Egan H, Kirk RS, Sawyer R. Pearson's chemical analysis of foods. $8^{\text {th }}$ edition. Great Britain: Longman Group Limited; 1981.

21. King RL, Dunkley WL. Relation of natural copper in milk to incidence of spontaneous oxidized flavor. J Dairy Sci. 1959; 42: 420.

22. Tuinsensor BT. Kit instructions-Doc: tuinsensor/V1.6. Available from: www.tuinsensor.com.

23. Bacteriological Analytical Manual (BAM) online, US Food and Drug Administration. Center for Safety and Applied Nutrition; January 2001.

24. Molnar PJ. Encyclopaedia of food science, Food Technology and Nutrition, Vol.6, R. Macrae, RK Robinson, MJ Sadler eds., London: Academic press, Harcourt Brace Jovanovich; 1993 pp. 3846-3850. 
25. FAO, Food and Agriculture Organization. Agriculture and consumer protection. The technology of traditional milk products in developing countries 2008. available from:

www.fao.org/docrep/003/to251eoo.ht $\mathrm{m}$.

26. Mistry VV, Pulgar JB. Physical and storage properties of high milk protein powder. Int. Dairy Journal. 1996; 6: 195-203.

27. Egyptian Standards. Maximum limits for heavy metals. Part 1: Maximum limits of lead in foods and Part 2:
Maximum limits of cadmium in foods.(2360-1). Arab Republic of Egypt: Egyptian Organization for Standardization and Quality Control; 2007.

28. Dharmanada S. Lead content of soil, plants, foods, air and Chinese herb formulas.2008. available from: www.itmonline.org/arts/lead.htm.

29. Elvira L, Sampedro L, Montero de Espinosa F, Mtesanz J, Gomez-Ullate Y. Resa P. et al. Eight-Channel ultrasonic device for non-invasive quality evaluation in packed milk. Ultrasonics. 2006; 45: 22-99. 